\title{
Research on Landscape Aesthetics Based on Ecological Ethics Education Construction*
}

\author{
Kefei Lin \\ College of Arts and Design \\ Beijing Forestry University \\ Beijing, China
}

\author{
Xixi Liu \\ College of Arts and Design \\ Beijing Forestry University \\ Beijing, China
}

\author{
Zhongying Shi \\ College of Arts and Design \\ Beijing Forestry University \\ Beijing, China
}

\begin{abstract}
On the basis of traditional aesthetics, contemporary western aesthetic circles add environmental aesthetics with ecological ethical thinking are trying to solve the increasingly serious ecological environment problems and subvert people's inherent values through its theory and practice. Landscape aesthetics, as an important branch of environmental aesthetics, should seek effective intervention of new ideas with epochal criticism on the basis of in-depth exploration of its historical form. This paper introduces art installations and landscape artifacts with animal and plant forms in landscape design and teaching, and explores the forms of interventional landscape and ecological ethics education concepts in practice, in order to provide theoretical and practical reference for solving ecological crisis and expanding the study of landscape aesthetics.
\end{abstract}

Keywords-landscape aesthetics; epochal criticism; ecological crisis; ethical participation; ecological education

\section{INTRODUCTION}

As a part of nature, human beings have natural and historical perception of natural beauty, and the theory of aesthetics in philosophy has a long history, so it is logical to intervene in natural ecological problems based on aesthetic research. By combing the rational and perceptual landscape aesthetics in the aesthetic tradition and the bias of landscape research in the development of the times, the study put forward the epochal criticism on the basis of exploring the theoretical basis and philosophical origin of landscape aesthetics.

\section{NATURAL AESTHETICS IN WESTERN LANDSCAPE TRADITION}

In 1750, aesthetics was first put forward by Baumgarten, a German philosopher. It is a subject of studying the aesthetic relationship between man and the world. Tracing

*Project: This paper is supported by "General Project of 2018 Education and Teaching Research of Beijing Forestry University"; Project No. (BJFU2018JY112) back to the origin of aesthetic history, it appeared in ancient Greece and Rome. Plato's aesthetic theory of "reasondivinity" occupies the main position. If the level of beauty is taken as a pyramid, the beauty of the body will be at the bottom, followed by the beauty of the spirit, the law or the system, and the beauty rationality is at the top. Plato believed that the rationale of beauty, that is, beauty itself and the essence of beauty, was an idealistic idea supremacy and spiritual supremacy, and no other individual thing of beauty could surpass it. The basic rationale of beauty was unified, neat and concise. It used the terms of harmony of numbers, quantification and scientificalization to explain the beauty and beauty laws. It was the philosophical thinking of beauty rather than the experiential feeling of beauty, and it had the trend of functionalism, that is, the unification of quantification and function. Plato's idea of "aesthetic rationality" influenced the gardening practice at that time which could be seen from a large number of ancient Roman gardening sites, such as Vilia Pliny at Toscane and Villa Laurentin. These ancient Roman manors are solemn and symmetrical, most geometric composition, with harmony quantitative proportion, which reflects the design principle of rational regulation.

Plato's philosophical theory on beauty has deeply influenced the history of western philosophy and aesthetics. Based on this, Plotinus developed Neo-Platonism. His aesthetic view has obvious theology, that is, the essence and source of beauty is ultimately attributed to divinity. Specifically, through perceiving the physical beauty of nature, the subject is purified, and then it is sublimated to the beauty of soul to achieve the beauty of unity of subject and object, and above the beauty of soul is the beauty of divinity, and beauty of divinity is to achieve the moral beauty of high unity of truth and goodness. Moral beauty is the beauty of loftiness, which is a restriction on oneself, a state of perfection for the purpose of others. Although ancient Greek philosophers emphasized the order of the world and neglected the objective existence of nature, this view provided a theoretical reference for ecological ethics in 
contemporary landscape aesthetics. Today, with increasingly serious ecological crisis, people need to have an equal attitude and moral care to the natural environment rather than wanton destruction, in order to form the so-called lofty moral beauty of Plotinus.

\section{THE PlACE SPIRIT OF WESTERN EMPIRICISM TRADITION}

There are two different directions and theories for western aesthetics and philosophy, and even for the tradition of western landscape architecture, namely, rationalism represented by Plato, Aristotle and Plotinus, and empiricism represented by F. Bacon and Locke. Different from the speculative aesthetics of classical metaphysics, empiricism is a bottom-up method with empiricism as its main principle.

An important school in the history of western landscape architecture: The British school of natural landscape architecture which is a typical representative of empiricism. The emergence of the British school of landscape architecture was facilitated by the landscape paintings that rose in the Netherlands in the 17 th century. It is a romantic trend of thought. Unlike idealism, which emphasizes the order of scientific unity, empiricism questions the so-called order of beauty, because there is no fixed standard to determine what order is beautiful. This is due to different logic between the subjective and the objective, and the embodiment of aesthetics should not be a fixed and unified form. Empiricism combines philosophical ideas with people's practical experience of landscape. Brown transformed many classical gardens into natural scenery parks, which made natural scenery parks appear in large numbers in Britain. Hogarth believed that all visual elements in the landscape can be summarized as lines in the best state, advocating the pursuit of "God-given lines". Today, the pursuit of line aesthetics in many modern landscape works also comes from this. The description of sense of beauty was so precisely embodied in Brown's practice in Burke's philosophical origin of lofty and aesthetic idea. It can be said that their three ideas are complementary to the spirit of the times, forming the belief of the British Natural Landscape Park: the landscape imitation reproducing the beauty of nature, and correcting the "unintentional loss" of nature [1].

Through exploring the origin of the tradition, the unique landscape aesthetic ideas and landscape practice style in different periods have been learned. These ideas provide a solid theoretical basis for the formation of contemporary landscape aesthetics. The greatest lesson that empiricism tradition brings to future generations is "spirit of place" [1]. This principle still occupies a dominant position in today's theory and landscape practice. It comes from "spirit of place as a whole". It emphasizes respect for site characteristics and consideration of planning as a whole. Just as today's landscape architects show great enthusiasm for maintaining local characteristics, maintaining local characteristics is a critique of the simplicity of copinism. It is that with the increasing trend of globalization today, under the premise of utilizing international and scientific construction technology, in order to meet the requirements of sustainable development, we should fully investigate the local topography, climate and soil properties to determine the landscape design scheme and use local building materials to minimize energy consumption, and plant local vegetation to reduce subsequent maintenance costs and root in local cultural traditions to awaken people's collective memory. Such is the concrete practice of "spirit of place". In this process, it is necessary to remain sober, not dogmatize the spirit of the place, and constantly change according to the requirements of the times, and give it a deeper value pursuit.

\section{STUDY ON CONTEMPORARY LANDSCAPE AESTHETIC EXPERIENCE AND LANDSCAPE PREFERENCE}

With the development of the times, the focus of landscape aesthetics exploration in the 20th century has changed from the previous classification and comparison of various beautiful things to the study on subject's landscape experience and landscape aesthetic preferences. This transformation has begun to regard nature and human as a unified whole, emphasizing the pleasant aesthetic sense that human beings acquire in natural experience. As a result, people's awareness of the protection of nature is aroused. These theories and methods further deepen the connotation of landscape aesthetics and the awakening of ecological consciousness.

\section{A. Study on the Subject's Own Experience of the Landscape}

American philosopher Santayana's aesthetics is a kind of naturalistic aesthetics, which regards aesthetics and aesthetics as a natural phenomenon, a natural nature inherent in human beings. It also reflects the irreplaceable role of nature in aesthetics. In his book Aesthetic Sense, Santayana argues that "beauty is the guarantee of the possible consistency between the mind and nature. Thus, it is the basis for belief in the supremacy of good deeds [2]." Stephen Brasa, an Australian geographer, also put forward a triple framework theory for landscape aesthetics: biological, cultural and personal [3]. The response to aesthetics is embodied in the laws of nature and it is a primitive impulse and tendency. For example, human beings like the environment that tends to be fresh in the air and the fragrance of birds and flowers, which is also the inspiration of today's study of landscape preferences. "Cultural" level is reflected in the addition of cultural factors to the natural landscape. Tao Yuanming's Peach Blossom Spring, for example, has created an aesthetic realm of peace and happiness for all, which has attracted countless people to Wuling to search for this paradise. Culture has endowed the natural beauty with more charming characteristics, which is fascinating. "Individual" refers to the transformation of natural landscape with innovative strategies, such as the stretching curve initiated by Brown, and the pursuit of line aesthetics has been existing in landscape design until now. Arnold Berlint, a famous representative of contemporary American environmental aesthetics, initiated participatory aesthetics on the basis of absorbing Dewey's empirical aesthetics and Husserl's phenomenology. It is an aesthetic theory that emphasizes experience and opposes the dualism thought since Kant's aesthetics, aiming at linking 
environmental ecology with aesthetics and emphasizing that man and nature are indivisible and unified whole [4].

\section{B. Landscape Preference from Biological Perspective}

From the biological point of view, it is possible to explain the inherent landscape preference and the law of natural aesthetic experience. Orion started from the origin of human evolution. He believed that the sparse grassland in eastern Africa was the most suitable for species to multiply and evolve. Therefore, humans like the similar landscape structure, namely the vast grassland, dotted with tall, lone trees and bushes. Appleton's "look and refuge theory" also explains landscape preferences through the principle of human evolutionary survival, just as primitive humans must hunt in order to survive without being found, which requires choosing a suitable place to avoid and observe. In the study of landscape preference, people often do not like to be exposed to the open space without shelter. In the specific landscape design, designers should pay attention to the relationship between vegetation planting and crime rate. Some overgrown jungles are more likely to induce crime, which is contrary to the refuge theory. The "information processing theory" infers the landscape features of complexity, mystery, consistency and readability by analyzing prehistoric human beings' conquest of animals stronger than themselves by means of wisdom and information processing. Starting from the primitive instinct of human beings, these biological explanatory theories are a kind of respect for nature, enrich the connotation of landscape aesthetics, and provide a principle reference for landscape designers to avoid mistakes. Starting from the primitive instinct of human beings, these biological explanatory theories are a kind of respect for nature, which enriches the connotation of landscape aesthetics, and provides a principle reference for landscape designers to avoid mistakes.

\section{Landscape Preference from Psychological Perspective}

The famous American landscape architect Jeffrey Jericho contributed a lot to the landscape in this period. He explored landscape design from a higher psychological point of view. He proposed that landscape design was "an activity that integrated the mind into the natural environment", which drew lessons from Freud and Jung's psychology, and embodied the importance and application of environmental psychology in today's landscape practice. Landscape preference is related to the psychological reaction of different groups and people at different stages. For example, studies showed that children generally liked landscape with water, while young and old people preferred familiar landscape, which reflected their dependence on birthplace and memory. It is helpful for us to have a deeper understanding of landscape aesthetics and to inherit and develop it by exploring the origin of landscape aesthetics from the biological and psychological perspectives.

\section{VALUE ORIENTATION AND ECOLOGICAL EDUCATION OF CONTEMPORARY LANDSCAPE AESTHETICS}

Nowadays, global warming has triggered the melting of Antarctic and Antarctic glaciers, and species extinction is becoming faster and faster, and the frequency of extreme weather is getting higher and higher. These realistic ecological crises have made the research of various specialties have a point of convergence, and interdisciplinary research is to solve ecological problems. Therefore, it is of great significance to integrate landscape aesthetics into ecological ethics and scientific knowledge and redefine the relationship between human and nature. The times have endowed the landscape aesthetics with new connotation. Taking the responsibility of the times as the basis of the landscape aesthetics, a contemporary shift from aesthetic pleasure to responsibility has emerged, which is the value orientation of the contemporary landscape.

\section{A. The Epochal Development and Research Achievements of Landscape Aesthetics}

Landscape aesthetics is an important branch of aesthetics with the development of the times. Its theoretical basis comes from the discussion of the aesthetic potential of landscape in western traditional aesthetics. Therefore, the discussion of landscape aesthetics has been centered on the relationship between rationality and sensibility. Therefore, it is necessary to always be vigilant, because the world is constantly developing, and science itself is a constantly falsified and evolving variant. The relationship between human beings and nature began to change from the moment when human beings were born. In the primitive hunting stage, human beings were a kind of religious natural view revering nature. In the agricultural civilization era, human beings depended on nature to live, and the progress of technology made human beings begin to imitate and transform nature. In the modern industrial society, the rapid advancement of science and technology has made people's unrestrained development and utilization of nature, leading to an ecological crisis. In the ecological civilization era of the twenty-first century, people are gradually awakening from the harm of industrial society to nature, questioning and subverting the values of human beings towards nature in the industrial age and rebuilding new values. In this process, many experts and scholars have devoted themselves to deeply discussing the relationship between human beings and nature and the role aesthetics should play in it and tried to change by using ecological knowledge and aesthetic traditions.

In 1949, Leopold put forward the concept of "earth ethics", which belongs to the category of moral philosophy. With its continuous development, as a result, the concepts of anthropocentrism and non-anthropocentrism were put forward, while non-anthropocentrism was a criticism of the traditional aesthetics of the dichotomy of subject and object, advocating the idea that man and nature should be one. Aaron Ness's deep ecology theory extends the research scope of ecology from natural science to eco-ontology philosophy, and "eco-ontology" has become the breakthrough point of Zeng Fanren's eco-aesthetics theory, a famous scholar in the 
field of contemporary domestic eco-aesthetics. He put forward that the problem of ecological aesthetics is, in the final analysis, a problem of human existence. Li Qingben called on aesthetics to include a moral feedback. Scholars at home and abroad are trying to promote the realization of fairness and justice in ecological dimension through aesthetic discourse. These research trends have exerted certain social influence, triggering a more detailed division of labor in the transformation of aesthetic ecology, such as the emergence of landscape aesthetics continuing the concept of ecological aesthetics. Landscape aesthetics and eco-aesthetics pay attention to different philosophical theories. Landscape Aesthetics pays more attention to practical research combined with landscape design. However, at present, both breadth and depth are still in the initial stage, and there are no theoretical works with deep explanatory power. Especially, the ecological aesthetic wisdom in the traditional cultures of the east and the west has not been fully explored. Therefore, this study explored the value orientation and specific ecological strategies used of landscape aesthetics from the traditional landscape aesthetic theory and landscape design practice.

\section{B. Awakening and Criticism of Human Ecological Consciousness}

"Sustainable development" as an ecological strategy of the times has been affirmed and supported by all walks of life. Contemporary landscape design practice guided by landscape aesthetics also follows the principle of sustainable development. For example, sponge city and rainwater garden use their scientific strategies to improve human living environment and ecological problems. So far, the biological, geographical and geological order surpasses the employer's needs. Human beings realize that the ecological crisis is essentially a value crisis. McHarg compared the role of human beings to "planetary enzymes". He believed that human beings should follow the operation of benign enzymes on the earth and aspired to become doctors of the world to govern the earth and themselves [5]. Human beings should have the ability of perception and regulation, that is, self-awakening, which is an ecological value based on studying the relationship between human beings and nature. It is necessary to be vigilant about the relationship between man and nature at all times, and consider whether imbalance or what it will bring to humanity. The idea of solving ecological crisis by human beings can never be solved by designing several drifting plans. The law of conservation exists at the moment of the birth of the natural universe. Without considering the consequences of the law of conservation of nature, it can only be destroyed faster. Thankfully, there are people who are constantly waking up and trying to make changes. Self-consciousness is self-help. As one of the achievements of this effort, landscape aesthetics also integrates discussion about ethics and psychology in the new era, which requires a correct value orientation to guide it to continue to move forward.

It is needed to inherit development and integrate innovation in a holistic and critical perspective. From a vertical historical point of view, that is, from the philosophical basis of aesthetics, mission and responsibility can be regarded as moral beauty, that is, divine beauty and lofty beauty advocated by Plotinus, which is a discussion about human ethics. This is related to the incorporation of responsibility-based ethics into landscape aesthetics. From the horizontal point of view, different countries in the world have different regional characteristics, different cultural values, and different practices created by landscape aesthetics. The same theory of landscape aesthetics can not be used to solve different environmental and ecological problems. During this period, it is needed to make use of science and technology to evaluate regional differences, including the investigation and analysis of historical culture, social development status and population psychology, especially to explore the ecological wisdom of regional traditional culture. In particular, we should explore the ecological wisdom in the traditional regional culture and make use of it. At first, landscape aesthetics based on aesthetics and ecology was integrated into ethics and psychology with the development of the times, so what kind of ideas and values should be integrated into landscape aesthetics in the future need to be further discussed. With no deviation, no extreme, it is possible to learn from the past to know the future. Only by tracing back to the origin of the event can people look wisely at the philosophical implications of today's social development and can people hold a dialectical and predictive criticism today when intelligent design gradually replaces natural selection.

\section{Construction of Ecological Ethics Education}

The most effective and basic way to raise awareness of ecological protection is to strengthen ecological education. The core of ecological education is the relationship between man and nature. The foundation of establishment is the relationship and order between people, from the establishment of ecological consciousness to ecological habits. The cultivation of the behavior is finally implemented into the norms of behavior, forming a harmonious and stable relationship between man and nature. The reason why human beings are trapped in today's predicament is precisely because it distorts the relationship between man and nature, and at the same time distorts people and people as well as social relationship. The "poetic habitation" advocated by Holderlin and Heidegger is the common aspiration of all, and the closer to danger, the more sober and self-help is important.

Eco-education is an important part of higher education and an important means of our "self-awareness" and "selfrescue". There are three main ways to realize ecological education. First, ecological ethics education is constructed and the ecological aesthetics professional curriculum system is perfected in universities. Only guaranteeing high-quality teaching resources and building a professional talent team can promote the development of disciplines and lay the foundation for the popularization of ecological education. The second is to carry out social practice activities with ecological education significance for the society. By carrying out green environmental protection activities, it is very important to carry forward the concept of ecological 
education, promote at the same time in breadth and depth, and establish a correct ecological morality for everyone, love nature, fear life, and subtly the impact of more people.

\section{CONCLUSION}

If human beings are sensitive to the aesthetic qualities of the world or nature, they will inevitably be aware of their responsibilities. Aesthetics and appreciation of the beauty also contain a kind of moral feedback [6]. This is a major shift in perceptual experience, and a strong self-help behavior of human beings as "planetary enzymes". Landscape aesthetics in the development of the times constantly critically refers to and absorbs different research methods and theoretical achievements and enriches its own theoretical construction. It also plays an active role in some ecological practices, which is conducive to strengthening its foresight of the problems of the times and the guidance of values.

\section{REFERENCES}

[1] Tang, J. (2004). A hundred years of questioning: Criticism on the value of western landscape architecture (pp. 41-58). Nanjing: Southeast University Press.

[2] Yan, G. Z. (2004). Comments on famous western aestheticians (Part Two)(pp. 140-142). Hefei: Anhui Education Press.

[3] Bourassa, S. (1991). The aesthetics of landscape. London \& New York: Belhaven Press

[4] Cheng, Z. X. (2019). Reflections on Berlint's criticism of Kant's aesthetics from the perspective of ecological aesthetics. Literature and Art Forum, 3, 114-116.

[5] McHarg. (2006). Design with nature (J. W. Huang, Trans.) Tianjin: Tianjin University Press.

[6] Li, Q. B. (2010). Ecological aesthetics abroad: A reader. Changchun: Changchun Publishing House. 